\title{
VENTRICULAR FIBRILLATION IN INDUCED HYPOTHERMIA
}

\author{
By Paolo Caldini, M.D.
}

Fellow, Cardiopulmonary Physiology, National fewish Hospital at Denver, Denver, Colorado

First proposed by Bigelow et al. (1950), the clinical use of hypothermia has become more widespread in the last eight years. Due to the fact that at low temperatures metabolic processes are reduced and oxygen demands are decreased, hypothermia has proved to be of great value in allowing the surgeon to perform intracardiac operations under direct vision with short-term circulatory occlusion. Unfortunately, this method has been shown to be rather hazardous, and in spite of the considerable experimental and clinical work several major risks remain to restrict its generalized use. The most serious complication, and by far the least understood phenomenon associated with hypothermia, is ventricular fibrillation.

\section{Mechanisms Predisposing to the Onset of Ventricular Fibrillation}

Because the lowering of body temperature produces profound changes in the physiology of some important systems of the homeothermic animal, the relationship between these changes and the frequent occurrence of ventricular fibrillation during hypothermia will be discussed under the following headings:

Respiration and blood $\mathrm{pH}$.

Plasma and myocardial electrolytes.

Myocardial excitability.

Nervous and hormonal control of the heart.

\section{Respiration and Blood $p H$}

Osborn (1953) showed that in non-shivering hypothermic dogs the arterial $\mathrm{pH}$ was reduced and the $\mathrm{CO}_{2}$ content was increased. He suggested that respiratory acidosis was present due to a depression of respiration. In his experiments there appeared to be a correlation between the lowering of the arterial $\mathrm{pH}$ and ventricular fibrillation. However, since the buffering capacity of cooled blood is enhanced by an increased amount of cations available in the plasma, owing to the reduction of protein ionization at lower temperatures, the fall in arterial $\mathrm{pH}$ during cooling can only in part be explained by the $\mathrm{CO}_{2}$ retention associated with respiratory acidosis.

Brewin et al. (1955) demonstrated the presence of a metabolic acidosis due to rise in lactate of production in animals and humans subjected to hypothermia. The cause of this rise is not very clear. In their experiments on hypothermic dogs, the lactate concentration of the blood increased considerably after ten minutes of circulatory arrest, and even more severe lactoacidosis usually developed during rewarming. Circulatory arrest associated with increased venous pressure may cause severe congestion of the liver and other viscera, leading to some derangement of theid functions.

Swan et al. (1953), on the basis of previous wor by Brown and Milles (1952), felt that ventricular fibrillation almost invariably occurs in animals in which hypercapnia and acidosis, present during periods of circulatory arrest, were abruptly corrected as circulation and respiration were resumed. They suggested that hyperventilation with oxygen throughout the hypothermic period is desirable in creating a state of respiratory alkalosis and constant arterial $\mathrm{pH}$.

Covino and Hegnauer (1955) also believed that in hypothermic dogs at temperatures below $25^{\circ} \mathrm{C}$., ventricular fibrillation is caused by the acidotic rather than the hypothermic state.

\section{Plasma and Myocardial Electrolytes}

Considerable attention has been given to the distribution of electrolytes in the intracellular and extracellular fluids in hypothermic animals and to its possible relationship with the onset of ventricular fibrillation

Electrolyte transfer depends not only on respective ion concentrations but also $\mathrm{pH}$ and steroid hormones. It depends also on the rate of cooling, presence or absence of shivering and type of anaesthesia used. Due to these multiple factors, lack of agreement still exists as to what changes in electrolyte concentration in the plasma and tissue occur in hypothermic animals. 
An increased plasma level of potassium has been reported in experimental hypothermia due to the diffusion of potassium ions out of the intracellular space (Bigelow et al., 1950). However, other investigators (Swan et al., 1953) found a decrease in potassium concentration in the plasma, not because there is an increased excretion of potassium with the urine, but probably because potassium enters the cells of various tissues.

Whatever the changes are in the level of the plasma electrolytes in the cooled animals, it seems reasonable to limit our discussion to the effective concentration of ions in the myocardial tissue itself. It is the direct effect of the distribution of these ions on each side of the cardiac cell membrane that can account for the increased myocardial irritability and the increased incidence of ventricular fibrillation in hypothermia.

Brooks et al. (1955), in their study on the excitability of the heart, conclude that a low potassium level in the myocardium enhanced considerably the excitability and spontaneous rhythmicity of the myocardial fibre. The effect of potassium is intimately related to the concentration of calcium in the extracellular fluid: a higher concentration of calcium further increases the effect of low potassium. Furthermore, Covino and Hegnauer (1955) observed a negative coronary artero-venous potassium difference and positive calcium difference in dogs at low temperature. They postulated that these changes are probably responsible for the increased excitability of ventricular musculature prior to the onset of fibrillation. Gollan et al. (1957) reported a negative potassium balance in cooled dog's heart; greater loss of potassium by the heart occurred when the animals were subjected to periods of acute hypoxia. If both experimental conditions were present, the risk of ventricular fibrillation increased considerably.

The plasma level of magnesium has been reported to be increased in induced hypothermia (Sunderman and Haymaker, 1947; Platner and Hasko, 1953). In a series of experiments (Caldini and Bromberger-Barnea, I958) on an isolated canine heart perfused with cooled blood from an intact donor animal, it was found that the magnesium artero-venous difference in the coronary blood was negative. Furthermore, the injection of small amounts of magnesium chloride directly into the coronary arteries of a cooled heart invariably resulted in ventricular fibrillation. The sensitivity to exogenous magnesium of the hypothermic isolated heart is more than double that of the normothermic heart.

The plasma concentration of sodium, chloride and other ions have not been shown to be not significantly affected by hypothermia.

\section{Myocardial Excitability}

Low temperatures have a profound effect on the excitability of the heart. During cooling the activity of the pacemaker is progressively depressed and sinus bradycardia occurs. Conduction of the excitation wave is markedly slowed, while both atrio-ventricular conduction and intraventricular conduction are depressed as is shown by a prolongation of the P-R and Q-S intervals in the electrocardiogram.

Depolarization of the cardiac cell membrane is only slightly affected by cold, while the repolarization of the cardiac cell membrane, and thus myocardial recovery, is considerably prolonged. It is known (Wiggers and Wegria, I939; Brooks et al., 1955) that during the late part of the refractory period of the myocardium at normal temperature, there are periods in which a partial recovery from the excitation is temporarily present. According to some investigators, if a single strong stimulus is exerted on the myocardium at that moment ventricular fibrillation occurs. Unfortunately, consistent data are not available for what happens at low temperatures. It is conceivable that during hypothermia the myocardium recovers from the excitation in a much less uniform manner than at normal temperatures.

In this laboratory (Bromberger-Barnea and Caldini, 1959), where trans-membrane potentials during hypothermia were measured and recorded in human subjects, non-uniform depolarization and repolarization of the myocardium during hypothermia was observed.

The non-uniform recovery of excitability of the single cardiac cell should favour the disrupting of the synchronization between single cardiac fibres and would favour the establishment of ventricular fibrillation.

Recently (Bromberger-Barnea and Caldini, 1958; Hogancamp et al., 1959) when transmembrane potentials of a cardiac fibre at the onset of ventricular fibrillation were recorded, it was observed that the normal intracellular pattern of depolarization and repolarization was completely lost. We have to conclude that ventricular fibrillation is probably not only due to a gross disorganization of muscle groups, but more probably is the result of profound changes in the function of every cardiac cell and its membrane.

\section{Nervous and Humoral Control of the Heart}

The possible influence of the autonomic nervous system on the heart in relation to ventricular fibrillation has been investigated by Shumacker et al. (1956). Bilateral upper dorsal sympathectomy and stellate ganglionectomy or blockade gave complete protection from ventricular fibrillation in a series of hypothermic dogs subjected to 
operative cardiac manipulation. Intravenous injection of sympathetic blocking drugs, such as Trimethaphen (Arfonad), was similarly effective, but to a lesser extent. Procaine block of the sinoauricular node has been shown to have a protective value, probably by interruption of sympathetic nerve supply to the heart (Riberi et al., 1956).

Stimulation of the right vagus nerve or coronary infusion with acetylcholine or neostigmine were considered effective in reducing the frequency of ventricular fibrillation in hypothermic dogs (Montgomery et al., 1954).

In contrast to these results, Brooks et al. (1955) noted an increased susceptibility to fibrillation in intact or isolated hearts with vagal stimulation. The mechanism whereby parasympathetic stimulation or sympathetic blockade are alleged to be effective in preventing ventricular fibrillation under experimental conditions is still unknown.

Epinephrine and norepinephrine both seem to increase susceptibility to ventricular fibrillation in dogs, probably by decreasing the level of resting excitability (Hoffman et al., 1955). The action of these sympathomimetic amines is most likely through a shifting of potassium from the intracellular space to the blood stream. An increased serum potassium concentration almost simultaneously accompanies the rapid fall in ventricular resting excitability.

It has been suggested that Somatropin (pituitary growth hormone) can decrease the incidence of ventricular fibrillation in hypothermia. According to Watkins et al. (1956) premedication with Somatropin would prevent ventricular fibrillation in hypothermic dogs subjected to right ventriculotomy and coronary artery ligation. They postulated that the intracellular potassium increased due to an acceleration of protein synthesis under the anobolic stimulus of Somatropin.

Due to general depression of metabolism at low temperature, the adrenal cortical function should progressively lessen with lowering of body temperature, and the pituitary adrenocorticotrophic hormones ought to behave in a similar fashion. No significant correlation has been observed between a decreased plasma level of these hormones and a high incidence of ventricular fibrillation.

\section{Conclusion}

The onset of ventricular fibrillation in hypothermia can be related to a series of different factors each of which has been substantiated by particular experimental conditions. Differences in techniques and experimental animals used have to be taken into account for the discrepancies reported by various observers.

In human hypothermia probably not one but several mechanisms play an important role in determining the frequent incidence of ventricular fibrillation.

\section{Early Electrocardiographic Signs of Impending Ventricular Fibrillation}

Several electrocardiographic changes occur in men and animals during hypothermia. Sinus bradycardia, increased P-R and Q-T intervals, widening of the QRS complex and changes in the amplitude and direction of the $T$ waves are frequently observed.

Osborn (1953) emphasized the appearance of a secondary wave at the junction of the QRS complex and ST segment as a sign of impending ventricular fibrillation. This current of injury was related to low $\mathrm{pH}$ and increased $\mathrm{CO}_{2}$ concentration in the arterial blood.

Some authors (Osborn, 1953; Milstein and Brock, 1954; Fleming and Muir, 1957) consider extrasystoles, runs of ventricular tachycardia and appearance of injury potentials as forewarning signs of the onset of ventricular fibrillation.

Although the electrocardiographic changes which have been described in hypothermia are probably related to an increased excitability of the myocardium, ventricular fibrillation in hypothermia frequently occurs without any previous changes in the electrocardiogram; and, on the other hand, marked changes in the electrocardiogram occur without the onset of fibrillation. In our experience, ventricular fibrillation cannot be predicted on the basis of changes in the electrocardiographic pattern.

\section{Prevention of Ventricular Fibrillation}

Even though ventricular fibrillation under any circumstance is a most serious condition, the danger of ventricular fibrillation in the hypothermic heart is greatly increased because of the difficulty encountered in converting it to a regular sinus rhythm by the counter-shock method.

At low temperatures it would appear that the heart has a diminished capacity to recover. Electrical defibrillation is often unsuccessful in reestablishing a regular sinus rhythm, or the ventricular contractions obtained are weak and ineffective. This fact has stimulated a large number of investigators to look for prophylactic measures aimed at avoiding such serious complications.

Numerous pharmacological agents or other methods have been tested for antifibrillatory properties during hypothermia. Table I lists some of the antifibrillatory drugs which have been tried. These drugs are supposed to be able to reduce the excitability of the cooled heart, to increase the velocity of excitation through the 
TABLE I

\begin{tabular}{|c|c|c|c|c|c|}
\hline Drugs* & Authors & Mechanisms of Action & Tested Against & Anaesthesia & $\begin{array}{l}\text { Incidence } \\
\text { of V.F.t }\end{array}$ \\
\hline $\begin{array}{l}\text { Neostigmine } \\
\text { (Prostigmine) } \\
\mathbf{1 . 2} / \mathrm{Kg} .\end{array}$ & $\begin{array}{l}\text { Montgomery et al. } \\
\text { (1954) }\end{array}$ & Parasympathetic properties. & $\begin{array}{l}\text { Dogs at } 25^{\circ} \text { and } \\
\text { operative cardiac } \\
\text { manipulation. }\end{array}$ & $\begin{array}{l}\text { Pentobarbital and hyper- } \\
\text { ventilation. }\end{array}$ & $0 \%(100 \%)$ \\
\hline $\begin{array}{l}\text { Quinidine } \\
\text { 30 mg./Kg. }\end{array}$ & $\begin{array}{l}\text { Stephenson et al. } \\
\text { (1956). }\end{array}$ & $\begin{array}{l}\text { Slowing the conduction and } \\
\text { lengthening the refractory } \\
\text { period of the heart. }\end{array}$ & $\begin{array}{l}\text { Dogs at } 27^{\circ} \text { and } \\
\text { occlusion of left } \\
\text { common coro- } \\
\text { nary artery. }\end{array}$ & $\begin{array}{l}\text { Pentobarbital and hyper- } \\
\text { ventilation. }\end{array}$ & $0 \%(100 \%)$ \\
\hline $\begin{array}{l}\text { Quinidine } \\
\text { 10 } \mathrm{mg} . / \mathrm{Kg} \text {. }\end{array}$ & $\begin{array}{c}\text { Berman et al. } \\
\text { (1958). }\end{array}$ & See above. & $\begin{array}{l}\text { Dogs at } 28^{\circ} \text { and } \\
\text { inflow-outflow } \\
\text { occlusion and } \\
\text { cardiac arrest } \\
\text { with acetylcho- } \\
\text { line. }\end{array}$ & & Ix \% ( $78 \%)$ \\
\hline $\begin{array}{l}\text { Procaine amide hydro- } \\
\text { chloride } \\
\text { (Pronestyl) } 0.8 \text { gr. }\end{array}$ & $\begin{array}{l}\text { Mavor et al. } \\
\text { (1956). }\end{array}$ & $\begin{array}{l}\text { Decreased cardiac excit- } \\
\text { ability. Decreased con- } \\
\text { duction time in the } \\
\text { auricle, bundle of His, } \\
\text { ventricular muscles. }\end{array}$ & Dogs at $28^{\circ}$ & & $27 \%(40 \%)$ \\
\hline $\begin{array}{l}\text { Procaine amide hydro- } \\
\text { chloride } \\
\text { (Pronestyl) } \\
\text { 25-50 mg./Kg. }\end{array}$ & $\begin{array}{l}\text { Haeger et al. } \\
\text { (1957). }\end{array}$ & See above. & $\begin{array}{l}\text { Rabbits at } 25^{\circ} \text { and } \\
\text { electrical stimu- } \\
\text { lation. } \\
\text { Dogs at } 25^{\circ} \text { and } \\
\text { operative cardiac } \\
\text { manipulation. }\end{array}$ & $\begin{array}{l}\text { Pentothal and hyperven- } \\
\text { tilation at } \\
25^{\circ} \text {. } \\
\text { Pentothal and } \\
\text { hyperventilation } \\
\text { at } 33^{\circ} \text {. }\end{array}$ & $\begin{array}{l}66 \%(95 \%) \\
22 \%(65 \%)\end{array}$ \\
\hline $\begin{array}{l}\text { Trimethaphen } \\
\text { (Arfonad) } \\
5 \text { mg.\%, contin- } \\
\text { uous intravenous } \\
\text { infusion. }\end{array}$ & $\begin{array}{l}\text { Riley et al. } \\
\text { (1957). }\end{array}$ & Sympatholytic properties. & $\begin{array}{l}\text { Dogs at } 17^{\circ} . \\
\text { Dogs at } 17^{\circ} .\end{array}$ & $\begin{array}{l}\text { Pentobarbital and hyper- } \\
\text { ventilation. } \\
\text { Thiopental and hyper- } \\
\text { ventilation. }\end{array}$ & $\begin{array}{l}44 \%(100 \%) \\
0 \%(53 \%)\end{array}$ \\
\hline $\begin{array}{l}\text { Piperidolate hydro- } \\
\text { chloride (Dactile) } \\
0.3-0.6 \mathrm{mg} / \mathrm{Kg} .\end{array}$ & $\begin{array}{l}\text { Hara et al. } \\
\text { (1957). }\end{array}$ & $\begin{array}{l}\text { Decreased cardiac excit- } \\
\text { ability. Increased re- } \\
\text { fractoriness. }\end{array}$ & $\begin{array}{l}\text { Dogs at } 27^{\circ} \text { and } \\
\text { operative cardiac } \\
\text { manipulation. }\end{array}$ & $\begin{array}{l}\text { Pentobarbital and hyper- } \\
\text { ventilation at } 33^{\circ} \text {. }\end{array}$ & $24 \%(97 \%)$ \\
\hline $\begin{array}{l}\text { Aminoacetic acid } \\
\text { (Glycine) } \\
0.8-1.5 \mathrm{gm} . / \mathrm{Kg} .\end{array}$ & $\begin{array}{l}\text { Beavers and Covino } \\
\text { (1957). }\end{array}$ & $\begin{array}{l}\text { Increased blood sugar and } \\
\text { plasma potassium levels. }\end{array}$ & $\begin{array}{l}\text { Dogs at } 25^{\circ} \\
\text { Dogs at } 25^{\circ} \text { and } \\
\text { operative cardiac } \\
\text { manipulation. }\end{array}$ & $\begin{array}{l}\text { Pentobarbital and hyper- } \\
\text { ventilation at } 30^{\circ} \text {. }\end{array}$ & $\begin{array}{l}0 \%(96 \%) \\
29 \%(93 \%)\end{array}$ \\
\hline $\begin{array}{l}\text { Mephentermine sul- } \\
\text { phate (Wyamine) } \\
\text { 3-5 mg./Kg. }\end{array}$ & Covino (1958) & $\begin{array}{l}\text { Decreased ventricular con- } \\
\text { duction time. Decreased } \\
\text { refractoriness. Suppres- } \\
\text { sion of ectopic foci. }\end{array}$ & Dogs at $25^{\circ}$. & $\begin{array}{l}\text { Pentobarbital and hyper- } \\
\text { ventilation at } 30^{\circ} .\end{array}$ & $37 \%(91 \%)$ \\
\hline $\begin{array}{l}\text { Ethylene diamine } \\
\text { tetracetic acid. } \\
\text { Disodium salt. } \\
75 \mathrm{mg} . / \mathrm{Kg} . \\
150-250 \mathrm{mg} . / \mathrm{Kg} . \\
\mathrm{KCl} .\end{array}$ & $\begin{array}{l}\text { Beavers and Covino } \\
\text { (I959). }\end{array}$ & Decreased plasma calcium. & Dogs at $25^{\circ}$. & $\begin{array}{l}\text { Pentobarbital and hyper- } \\
\text { ventilation at } 30^{\circ} \text {. }\end{array}$ & $50 \%(96 \%)$ \\
\hline
\end{tabular}

-All drugs were injected intravenously. †Percentages in parentheses represent the incidence of ventricular fibrillation in the control animals.

conduction system and the ventricles, or to prevent or suppress ventricular ectopic foci. Some of these agents have been shown to be rather effective on an experimental basis, but clinical trials have only partially substantiated their antifibrillatory properties. Once again, different experimental animals and types of anaesthesia used and lack of standardization in the method of testing make it very difficult to establish the relative effectiveness of these agents.

One method to solve this problem is based upon the fact that a heart at normal body temperature is considerably less irritable and that the incidence of ventricular fibrillation is rather negligible. Thus it was felt that in hypothermia the incidence of ventricular fibrillation would certainly be reduced if the heart is artificially kept at $37^{\circ} \mathrm{C}$. Jude et al. (1956) used arterial normothermic blood to perfuse the coronary arteries during circulatory occlusion in dogs at $27^{\circ} \mathrm{C}$. They were successful in abolishing the incidence of ventricular fibrillation and cardiac failure on reestablishment of normal circulation. Kaflan and Fischer (1958) achieved the same results in dogs by using a pericardiac space perfusion with warm saline to increase cardiac temperatures above $35^{\circ} \mathrm{C}$. These experiments, although quite encouraging, have not been substantiated in humans.

We have to conclude that reliable antifibrillatory drugs and techniques able to prevent the onset of ventricular fibrillation in human hypothermia are still not available. Every measure and precaution has to be taken in the induction of hypothermia and during operative cardiac manipulations to reduce to a minimum the incidence of this dangerous arrhythmia. 


\section{Treatment of Ventricular Fibrillation}

Spontaneous ventricular defibrillation rarely, if ever, occurs in man; injection of $I$ per cent. procaine directly into the left ventricle with continuous cardiac massage is sometimes successful in restoring spontaneous co-ordinated ventricular contractions (Milstein and Brock, 1954). Electrical counter-shock is certainly the most efficient method of reverting the heart to a normal sinus rhythm. If coronary circulation has been adequately maintained with oxygenated blood by a continuous manual massage of the heart and no coronary embolism is present, electrical defibrillation is easily achieved.

Nevertheless, during hypothermia in some patients, difficulty is encountered in restoring a normal heart beat. In experimental as well as human hypothermic hearts the injection of tetraethylammonium chloride into the coronary arteries through coronary perfusion has been employed with success at the National Jewish Hospital; I-2 mg. tetraethylammonium chloride (TEA) per $\mathrm{kg}$. of body weight always allows electrical defibrillation with ease in hearts in which the electrical counter-shock was ineffective before the application of TEA. TEA probably exerts its effect by antagonizing the fibrillatory action of excess magnesium present in the hypothermic heart. Because of the positive inotropic action on the myocardium of TEA, it also helps in restoring forceful and sustained ventricular beats (Caldini and Bromberger-Barnea, 1958).

Coronary infusion with a 5 per cent. solution of potassium chloride followed by a 5 per cent. solution of calcium chloride has also been employed with success to stop ventricular fibrillation in hypothermia. However, the use of potassium is not completely satisfactory. It is clear that potassium injected in the right amount abolishes ventricular fibrillation, but at the same time rapidly depresses the conduction, contraction and rhythm of the heart. When calcium is injected, too many ectopic foci are produced and the ventricles often revert to fibrillation.

\section{Conclusion}

In spite of the significant risk of ventricular fibrillation occurring during hypothermia, this method is still extensively used in open cardiac operations. Our knowledge is continuously improving as to which mechanisms are involved in the onset of ventricular fibrillation in hypothermia and the methods of preventing it. If this risk could be completely abolished and the body temperature safely reduced to a lower level to allow longer circulatory occlusion, hypothermia might very well be the best single method for open cardiac surgery.

\section{BIBLIOGRAPHY}

BEAVERS, W. R., and COVINO, B. G. (1957), A.M.A. Arch. Surg., 75, 776.

BEAVERS, W. R., and COVINO, B. G. (1959), f. appl. Physiol., 14, 1959.

BERMAN, E. J., TAYLOR, M. T., and FISCH, C. (1958), $\mathfrak{f}$. Thorac. Surg., 35, 483 .

BIGELOW, W. G., CALLAGHAN, J. C., and HOPP, J. A. (I950), Ann. Surg., 132, 521.

BIGELOW, W. G., LINDSAY, W. K., and GREENWOOD, W. F. (1950), Ann. Surg., 132, 849.

BREWIN, E. G., GOULD, R. P., NASHAT, F. S., and NEIL, E. (1955), Guy's Hosp. Reports, 104, 1955.

BROMBERGER-BARNEA, B., and CALDINI, P. (1958), 3rd World Congress of Cardiology, Abstracts of Communications, p. 74. BROMBERGER-BARNEA, B., CALDINI, P., and WITTENSTEIN, G. J. (1959), Circulation Res., 7, 138.

BROOKS, C. McC., HOFFMAN, B. F., SUCKLING, E. E., and ORIAS, O. (1955), 'Excitability of the Heart,' Grune \& Stratton, New York.

BROWN, E. B., Jr., and MILlER, F. (1952), Amer. F. Physiol., 169, 56.

CALDINI, P., and BROMBERGER-BARNEA, B. (1958), Science, 128, 1435.

COVINO, B. G., and HEGNAUER, A. H. (1955), Circulation Res., 3, 575 .

COVINO, B. G. (1958), f. Pharmacol., 122, 418

FLEMING, P. R., and MUIR, F. H. (1957), Brit. Heart F., 19, 59. GOLLAN, F., GUILFORD, G. R., and OLSEN, N. S. (1957), Amer. F. Physiol., 189, 277.

HAEGER, K., and SJOSTRÖM, B. (1957), Acta chir. scand., I13, 167.

HARA, M., HARBERG, F. J., and HUDSON, L. H. (1957), A.M.A. Arch. Surg., 75, 780.

HOFFMAN, B. F., SIEBENS, A. A., CRANEFIELD, P. F., and BROOKS, McC. (1955), Circulation Res., 3, 140.

HOGANCAMP, C. E., KARDESCH, M., DANFORTH, W. H., and BING, R. J. (1959), Amer. Heart $\mathscr{f}$., 57, 214

JUDE, J. R., FAUTEAUX, J. P., and HAROUTUNIAN, L. M. (1956), S. Forum, 7, 294.

KAFLAN, A., and FISCHER, B. (1958), A.M.A. Arch. Surg., 77, 319.

MAVOR, G. E., HARDER, R. A., EMERSON, G. L., and MAHONEY', E. G. (1956), $\ddot{f}$. thorac. Surg., 31, 744.

MILSTEIN, B. B., and BROCK, R. (1954), Guy's Hosp. Rep., 103, 1954 .

MONTGOMERY, A. V., PREVEDEL, A. E., and SWAN, H. (1954), Circulation, 10, 721 .

OSBORN, J. J. (1953), Amer. f. Physiol., 175, 389.

PLATNER, W. S., and HASKO, M. J. (1953), Amer. F. Physiol., 174, 273.

RIBERI, A., SYDERIS, H., and SHUMACKER, H. B., Jr. (1956), Ann. Surg., 143, 216.

RILEY, P. A., Jr., MIXON, B. M., Jr., and BARILA, T. G. (1957), Surgery, 42, 936.

SHUMACKER, H. B., Jr., RIBERI, A., BOONE, R. D., and KAJIKURI, H. (1956), Ann. Surg., I43, 223.

STEPHENSON, S. E., Jr., and MAIN, F. B. (1956), S. Forum, 7, 278.

SUNDERMAN, F. W., and HAYMAKER, W. (1947), Amer. $\mathcal{F}$. med. Sci., 213,562 .

SWAN, H., ZEAVIN, I., HOLMES, J. H., and MONTGOMERY, V.'(1953), Ann. Surg., 138, 360 .

WATKINS, D. H., PREVEDEL, A. E., MUNRO, G. A., ROTHMAN, S., and HILL, R. H. (1956), $\mathcal{F}$. thorac. Surg., 32,583 .

WIGGERS, C. J., and WEGRIA, R. (1940), Amer. F. Physiol., 